\title{
Financial Behavior during COVID-19: Cognitive Errors That Can Define Financial Future
}

\author{
Monica Dita Pravita Widya Putri*, Chaoyi Xu, Larsey Naphtali Akwetteh \\ School of Economics and Management, Anhui University of Science and Technology, Huainan, China \\ Email: ^monicadpwp@gmail.com,3910379@qq.com,nlarsey.nl@gmail.com
}

How to cite this paper: Putri, M. D. P. W., Xu, C. Y., \& Akwetteh, L. N. (2020). Financial Behavior during COVID-19: Cognitive Errors That Can Define Financial Future. Open Journal of Social Sciences, 8, 259-269. https://doi.org/10.4236/jss.2020.810017

Received: September 20, 2020

Accepted: October 26, 2020

Published: October 29, 2020

Copyright $\odot 2020$ by author(s) and Scientific Research Publishing Inc. This work is licensed under the Creative Commons Attribution International License (CC BY 4.0).

http://creativecommons.org/licenses/by/4.0/

(c) (i) Open Access

\begin{abstract}
Purpose: The purpose of this study is to determine the economic effects caused by the crisis impact of the COVID-19 pandemic. Methodology: We explored various kinds of literature from various journals to find out the level of trust and financial behavior of the public during the COVID-19 pandemic. Results and findings: The phenomena that occurred during the crisis due to the COVID-19 pandemic, such as excessive volatility and the confidence of unaffected financial institutions, cannot be explained through the traditional market paradigm. In this paper, we explore this phenomenon from a behavioral finance perspective and discuss some relevant cognitive errors and biases during and after the crisis due to the COVID-19 pandemic. Limitation: The study explains by exploring the phenomenon from the viewpoint of financial behavior and discussing some of the relevant cognitive errors during and after the crisis. We only look at each phenomenon from a psychological point of view and consider its relevance to financial institutions and markets as well as the financial crisis due to the COVID-19 Pandemic.
\end{abstract}

\section{Keywords}

Behavioral Finance, Human Psychology, COVID-19 Pandemic, Financial Crisis

\section{Introduction}

The SARS-CoV-2 virus or better known as Coronavirus or COVID-19, which has attacked various parts of the world, has produced dramatic economic effects, marked by excessive volatility in stock prices and falling markets (Bansal, 2020). The COVID-19 pandemic has also negatively affected the performance of companies around the world through shocks from supply and demand caused by lockdowns carried out by several countries (Ozili \& Arun, 2020). According to the International Monetary Fund (IMF), for the first time, major depression has 
hit both developed and developing countries and has the potential to experience a recession. Economic growth in developed countries is projected to be at the level of -6.1 percent while emerging markets with normal growth rates are projected to be at the level of -1.0 percent in 2020 , and -2.2 percent if China excludes in its calculations (Gopinath, 2020).

During late February to March 2020, global stock markets were characterized by the extraordinary volatility induced by COVID-19 (Baldwin \& di Mauro, 2020). As of March 27, 2020, the top 10 countries that had been infected (including South Korea, Japan, and Singapore, and excluding India) had an increased risk of 26.8 percent from February to March 2020 (Zhang et al., 2020). Anomaly reports in the theory of efficient traditional markets appear inappropriate if they are not presented with significant evidence against the theory so that markets and humans are most logical and master efficient self-management and fail to portray dramatic volatility (Shiller, 2003). This volatility can also be described by the behavioral finance paradigm (Olsen, 1998).

Financial behavior states that investors and markets are not fully rational and investors are controlled by speculation and cognitive refraction because of the attachment of rationality (Danepo, 2018). It consists of two main parts, namely, psychology which will explain fallibility in the concept of human behavior, and the limit of arbitration which argues that the economy of commerce is rational and irrational (Herschberg, 2012). Irrationality has a significant sustainable impact (Bansal, 2020). This paper examines some of the common cognitive biases and some of the related phenomena in behavioral finance as observed in the COVID-19 pandemic impacting the current global crisis.

\section{Cognitive Errors and Financial Crisis}

\subsection{Overconfidence and Miscalibration}

Overconfidence is one of the psychological theories which consists of four main aspects, namely calculation errors, better than average effects, the illusion of control, and unrealistic optimism (Bondt, 1998). Being overly confident about the comparability of personal information can help confirm reactions under and in the securities market and lead to stock price volatility (Biais et al., 2005). Since volatility is a major peculiarity of the market during the crisis due to the COVID-19 pandemic (Su, 2020), four aspects of overconfidence have been explored in the following sections related to financial behavior and participation in financial markets in 2020. Where imperfect behavioral finance has replaced the paradigm of classical finance but is an alternative solution to the difficulty in explaining certain behavioral finance phenomena (Birau, 2012).

\subsubsection{Miscalibration}

Miscalibration shows that executives can reduce the lower bound of the estimated confidence interval during times of high uncertainty, but ex-post calculation errors are the worst during periods of high uncertainty (David et al., 2013). This miscalibration can also have serious consequences (Lichtenstein et al., 
1977), namely excessive trust which can be defined as a certain type of calculation error, namely high self-confidence cognitive bias and accuracy (Bansal, 2020). Overconfidence from this point of view illustrates one important reason and is in line with the financial sector (Scale, 2008). Especially in the understanding of financial recognition to be able to share the correct calibration incentives is inefficiency and excessive trust especially in difficult tasks or better known as the hard-easy effect (Fischhoff et al., 1977).

This cognitive bias is clearly reflected in projections of GDP growth worldwide as the COVID-19 pandemic expands. Especially in Indonesia, the projected GDP growth throughout 2020 is mismanaged so that the resulting figure is higher than the actual figure, even when investors find it in other developing and developed countries. According to a report from Bank Indonesia (BI) which refers to a report from the Ministry of Finance of the Republic of Indonesia, GDP for Indonesia several times from March to early August experienced a decline ranging from 0.2 percent to 0.5 percent with the most significant decrease occurring in June of 0.5 percent (Table 1 ). The projected growth rate for Indonesia has not increased significantly but is still at high risk of importing COVID-19 (Trading Economics, 2020).

Table 1. GDP growth rate projection and confirmed cases in Indonesia (2020) (Kasus Covid-19, 2020; Trading Economis, 2020).

\begin{tabular}{ccccccc}
\hline Date & Projected Growth Rate & $\Delta$ Projection & Cases & $\Delta$ Cases & Recovery & $\Delta$ Recovery \\
\hline Mar. 2, 2020 & $2.98 \%$ & $+10.07 \%$ & 2 & - & - & - \\
Apr. 2, 2020 & $2.96 \%$ & $-0.67 \%$ & 113 & $5550 \%$ & 9 & - \\
May 2, 2020 & $2.67 \%$ & $-52.38 \%$ & 292 & $158.41 \%$ & 74 & $722.22 \%$ \\
Jun. 2, 2020 & $2.19 \%$ & $-17.98 \%$ & 609 & $108.56 \%$ & 298 & $302.70 \%$ \\
Ju.1 2, 2020 & $1.96 \%$ & $-10.50 \%$ & 1624 & $166.67 \%$ & 1072 & $259.73 \%$ \\
Ags. 2, 2020 & $1.54 \%$ & $-21.43 \%$ & 1519 & $-6.47 \%$ & 1056 & $-1.49 \%$ \\
\hline
\end{tabular}

\subsubsection{Better-Than-Average-Effect}

The Better-than-average-effect is considered to be one of the most powerful of all self-enhancing phenomena (Taylor \& Brown, 1988) (Sedikides \& Gregg, 2003). In this case, people who have a positive and unrealistic view of themselves and consider them superior to representatives of other groups (Skala, 2008). In the financial sphere, the securities given exceed the average and have been shown to correspond to a much higher trading volume (Glaser \& Weber, 2007). This happens because traders think the information they have is much better than their peers. A specific example can again be seen from the company structure where CEOs and managers who are too confident and always consider themselves superior and have been proven to influence existing policies and invest excessively (Bansal, 2020). In this context, it shows that the role of managers is too excessive and has high self-confidence so that they think they can assess the sustainability of positive conditions and underestimate the risks of their in- 
vestments (Ho et al., 2016).

This has led to the phenomenon of "overconfident banks" to ease the standard of borrowing, increase the number of loans, increase leverage, and may incur additional debt to be borne. Shortly after the financial crisis began (in 2008), overconfident banks experienced significantly higher capital losses, there was a severe decline in their net value, and a higher probability of replacement and subsequent CEO failures from overconfident banks (Sironi \& Suntheim, 2012). Therefore, financial institutions that are overconfident are characterized by the risky investments they made prior to the Sahan Market accident in 2020, and tend to experience much higher losses and failures after the crisis occurred. It is also a reflection for the coming years which will be marked by more conservative investment and risky lines.

\subsubsection{Illusion of Control}

In psychological research illusion of control is shown as an expectation of the probability of personal success which is inappropriately higher than the objective probability (Langer, 1975). This suggests that people tend to admit that they can influence events that may have happened by chance (Taylor \& Brown, 1994). It is suspected that the factors that influence it are factors from skill situations such as rivalry, preferences, closeness, and implications that are included in the incidental situation causing the individual to feel insecure (King et al., 2018). Other illusions of control that can affect the market are stress, competition, and an implemental mindset which has shown to be conducive to the development of the illusion of control and result in maladaptive behavior for traders (O'Creevy et al., 2003). This aspect is a characteristic of the 2008 Financial Crisis of overconfidence in the risk management model being implemented which caused a financial bubble to burst which was a specific illusion of control.

The illusion of control is also common when there is a violent reaction to a crisis such as during the COVID-19 pandemic. Now the study carried out on the basis of the disclosure analysis carried out in the income conference call and the 10-K formula from the company during Q1 in 2020 reveals that there is a negative market reaction (JPMorgan, 2020). This suggests that currently the market has underestimated the impact of the COVID-19 pandemic on companies (Wang \& Xing, 2020).

\subsubsection{Unrealistic Optimism (Optimism Bias)}

The optimism bias has a strong enough relationship and has a better than average effect (Zíka \& Koblovský, 2016) on point 2.1.2. People with this optimism bias have sufficient confidence that they have the potential to experience a positive event rather than a negative event, especially if the event is perceived as a controllable event (Harris et al., 2008). In the financial sector, some people believe that the opportunity they currently have to be able to achieve financial success will have a position that will be bigger than others (Skala, 2008). The use of the optimism bias was also commonly used during the financial crisis in 2008 because of the untested model that was justified with a transient optimism atti- 
tude and minimized negative possibilities (Wang \& Xing, 2020).

Biased optimism can also be seen in the current crisis. Even as banks that have seen their profits plummet and forecast losses due to loans that topped the billions during the 2020 Stock Market Crash, investors remain as optimistic as they were from the start (Helms, 2020). The United States Federal Reserve system has currently cut interest rates, purchased bonds, and provided assistance, and supported the credit market (Westbrook, 2020).

\subsection{Representation Bias}

Representation bias is a cognitive tendency for investors to be able to influence their behavior on the stock market (Zhao \& Fang, 2014). The representation bias in this case is a cognitive bias where people can relate to their analogs and can predict the future of analogs, especially in the horizontal representation bias (Zhang, 2008). In the literature on financial behavior, this bias has an impact on the quality of investment (Zhao \& Fang, 2014). Investors often position past returns as a representation of the potential for future returns, therefore it is found that there is a trend of the future in terms of returns (Bondt, 1998).

The beginning of 2020 and its peak in mid-2020 is the collapse of the stock market as a result of the current COVID-19 pandemic and has been found several times in the discussion of other papers that equate to the financial crisis in 2008 and the great depression that occurred in the 1930s (Brende, 2020). The above comparison is a concrete example of representation bias. Statman has warned that while the current market conditions may appear analogous to early 2009 when the stock market fell and turned into a sharp rise, current market conditions may have represented the stock market conditions in the late 1930s, this happened because when there was a decline it did not reach its peak until 1932 (McCaffrey, 2020). The resulting biased comparisons can have an immediate negative impact on the market in the long run, because they are only sentiment-based representations.

\subsection{Risk Aversion}

Risk Aversion is a theory of the unexpected utility of choice under uncertainty and describes a decrease in preference to increasing risk (the difference between the expected value of the considered action and its certainty equivalent) (Montesano, 1990). In this phenomenon, there is a reluctance to look for a higher risk and instead, prefer a lower-risk alternative. This risk aversion can be significantly identified and affected during extraordinary situations. Especially investors are divesting more stocks and risk aversion which increased substantially after the 2008 financial crisis (Guiso et al., 2018).

During the time of the COVID-19 pandemic and the stock market crash of 2020 , financial avoidance will also change. The existing risk aversion in Wuhan was found to increase substantially followed by the rapid spread of COVID-19 in the city ( $\mathrm{Bu}$ et al., 2020). In addition, gold has always been considered the safest, and its value also increases with investment risk (Demirer et al., 2019). Gold 
prices rose by $6.72 \%$ (USD)/7.49\% (EUR)/15.93\% (IDR) on 24 July 2020 (YCharts, 2020), thus providing additional evidence that risk aversion has improved the function of COVID-19 against global in crisis. Figure 1 presents the trend of the long-term ratio of gold (USD) for a period of 7 months (from 2 Janurai-28 July 2020). The falling ratio started in February which shows the increase of Risk Aversion. While Figure 2 presents the ratio of DJIA to gold price (USD) for 7 months from January to July 2020. However, it is important to note that the DJIA is a price index that is different from the total return index and is therefore not included in dividends. Meanwhile, further research into the same possible increase in risk aversion will signal the behavior of investors around the world.

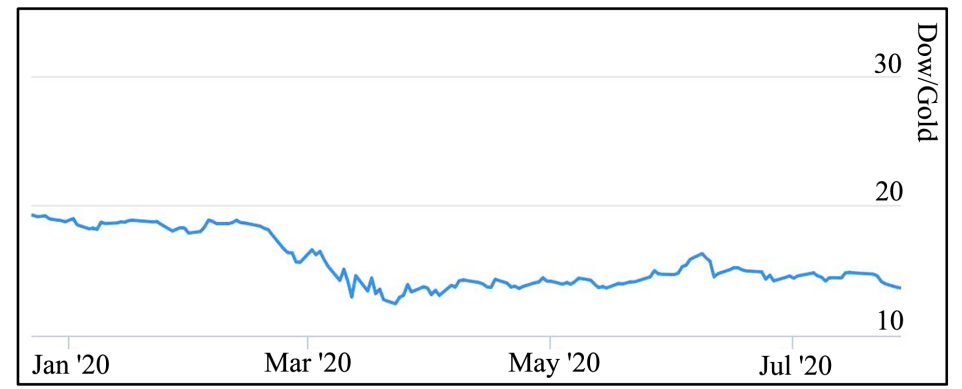

Figure 1. Long term trends/gold ratio (Jan. 2-July 28, 2020).

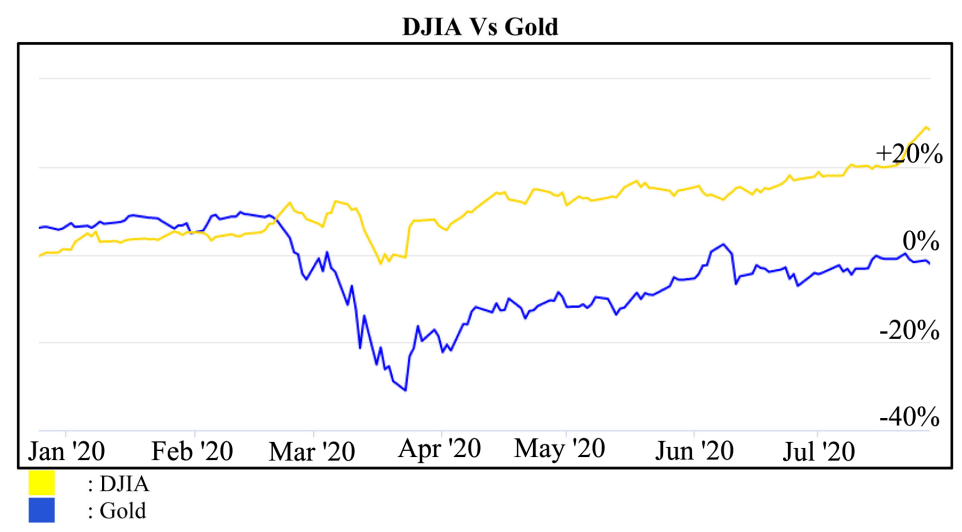

Figure 2. DJIA vs gold/ gold ratio (Jan. 2-July 28, 2020).

\subsection{Herding Behavior}

The information cascade theory is that the user's decision making will be influenced by two elements: one is the user's understanding of relevant information and the other is the choice of others (Liu \& Zhang, 2014). This phenomenon causes many people to make the same decisions in succession. This is a theory that has a herding characteristic, where traders will ignore their personal information and instead trade according to their preferred trading patterns (Bansal, 2020). In the case of the Asian Financial Crisis of 1997/1998, transmission increased initially and herding behavior continued throughout the crisis at a later stage (Chiang et al., 2007).

The current fluctuation of the market crisis can be a reason to be able to in- 
vestigate any changes in financial behavior (Banchit et al., 2016) to bring investors back to the global market and restore their level of confidence. Interestingly, in the cryptocurrency market, there has been no significant change in behavior leading to at least recorded until March 2020 (Yarovaya et al., 2020). Although in practice the cryptocurrency market has no linkage with global markets (Giudici et al., 2020), they are concentrated and thus may not spontaneously be compared with traditional financial market behavior in terms of herding behavior (Senarathne \& Wei, 2020). Further assessment is needed to consider the herding behavior that seems unusual.

\subsection{Availability Heuristics}

The availability of heuristics has been widely cited as the most important factor in the assessment process (Manis et al., 1993). In this case, the availability heuristic or availability bias is a cognitive error where the assessment system is carried out on the basis of examples that usually appear in the picture (Bansal, 2020). However, the evidence that availability is important in assessing the size of the category is not completely conclusive (Viswanathan et al., 2017). In the context of the discussion on financial behavior, either investors or financial institutions who have believed in the capabilities of risk management for a long time will get results that tend to be positive (Härle et al., 2007). Excessive interpretation of the capabilities of risk management and the existence of over-dependence on investors and the market will increasingly lead to estimates of true risk. Furthermore, there is an increase in market entry, more loans, cheaper access to funding, looser regulations, and high-risk investments which will ultimately lead to a global crisis (Thakor, 2015). Building on the financial crisis that occurred in 2008 has been characterized by several of these theories.

Public trust in financial institutions and markets has tended to show an increase in recent times after the financial crisis that occurred in 2008 (Uslaner, 2010). Although the discussion and literature on public confidence in financial institutions over the fall of the stock market in early to mid-2020 (Moore, 2020) are very limited and most of the literature is characterized by uncertainty, it is important to recognize the bias of availability and readjustment to the expectations of investors. The turmoil and crisis on financial markets have provided evidence of the impact of a very significant decline in public confidence and a bias from acceptance which encourages investors to put more emphasis on current events (Wälti, 2012). Therefore, if the impact on the market shows a much larger impact, there will be a decrease in public confidence in the financial system which will also affect market performance in the coming year.

\section{Conclusion}

The global crisis caused by the COVID-19 pandemic that is currently hitting various parts of the world, we tend to focus on what is considered the easiest for us to be able to access and get information directly during this pandemic in 
order to adapt to the ongoing crisis. This is very ironic because, considering the current global crisis, we should be more careful. It is very important for us to be able to consider our subconscious biases in order to decide the right action to take next. Some of the cognitive phenomena in the behavioral financial background associated with the COVID-19 pandemic are described in this paper, namely the existence of over-confidence, representation bias, risk-aversion, herding behavior, and availability bias. There are greater cognitive errors found outside the financial behavior that we do in our daily lives. But in this paper, we hope to serve as a reminder of the psychological deficiencies that can help us to better navigate from future crises and not make the same mistakes as crises in the past.

\section{Conflicts of Interest}

The authors declare no conflicts of interest regarding the publication of this paper.

\section{References}

Baldwin, R., \& di Mauro, B. W. (2020). Mitigating the COVID Economic Crisis: Act Fast and Do Whatever It Takes. London: CEPR Press.

Banchit, A., Abidin, S., \& Wu, J. (2016). Are Shares More Volatile during the Global Financial Crisis? Procedia-Social and Behavioral Sciences, 224, 221-229. https://doi.org/10.1016/j.sbspro.2016.05.448

Bansal, T. (2020). Behavioral Finance and COVID-19: Cognitive Errors That Determine the Financial Future. SSRN, 1-6. https://doi.org/10.2139/ssrn.3595749

Biais, B., Hilton, D., \& Mazurier, D. K. (2005). Judgemental Overconfidence, Self Monitoring, and Trading Performance in an Experimental Financial Market. Review of Economic Studies, 72, 287-312. https://doi.org/10.1111/j.1467-937X.2005.00333.x

Birau, F. R. (2012). The Impact of Behavioral Finance on Stock Markets. Annals of the Constantin Brâncuşi” University of Târgu Jiu, Economy Series, 3, 45-50.

Bondt, W. F. D. (1998). A Portrait of the Individual Investor. European Economic Review, 42, 831-844. https://doi.org/10.1016/S0014-2921(98)00009-9

Brende, B. (2020). Great Recession Showed Countries Can't Fight the Coronavirus Economic Crisis Alone.

https://www.weforum.org/agenda/2020/04/covid-19-coronavirus-economic-crisis-grea t-recession/

Bu, B., Hanspal, T., Liao, Y., \& Liu, Y. (2020). Risk Taking during a Global Crisis: Evidence from Wuhan. Technical Report-Working Paper. https://doi.org/10.2139/ssrn.3559870

Chiang, T. C., Jeon, B. N., \& Li, H. (2007). Dynamic Correlation Analysis of Financial Contagion: Evidence from Asian Markets. Journal of International Money and finance, 26, 1206-1228. https://doi.org/10.1016/j.jimonfin.2007.06.005

Danepo, M. (2018). Pengaruh Bias Perilaku Investor Terhadap Keputusan Investasi di Pasar Saham (Studi Kasus pada BEI). Bandar Lampung: Universitas Lampung.

David, I. B., Graham, J. R., \& Harvey, C. R. (2013). Managerial Miscalibration. The Quarterly Journal of Economics, 128, 1547-1584. https://doi.org/10.1093/qje/qjt023

Demirer, R., Gkillas, K., Gupta, R., \& Pierdzioch, C. (2019). Time-Varying Risk Aversion 
and Realized Gold Volatility. The North American Journal of Economics and Finance, 50, Article ID: 101048. https://doi.org/10.1016/j.najef.2019.101048

Fischhoff, B., Slovic, P., \& Lichtenstein, S. (1977). Knowing with Certainty: The Appropriateness of Extreme Confidence. Journal of Experimental Psychology: Human Perception and Performance, 3, 552-564. https://doi.org/10.1037/0096-1523.3.4.552

Giudici, G., Milne, A., \& Vinogradov, D. (2020). Cryptocurrencies: Market Analysis and Perspectives. Journal of Industrial and Business Economics, 47, 1-18. https://doi.org/10.1007/s40812-019-00138-6

Glaser, M., \& Weber, M. (2007). Overconfidence and Trading Volume. The Geneva Risk and Insurance Review, 32, 1-36. https://doi.org/10.1007/s10713-007-0003-3

Gopinath, G. (2020). The Great Lockdown: Worst Economic Downturn since the Great Depression. IMFBlog.

https://blogs.imf.org/2020/04/14/the-great-lockdown-worst-economic-downturn-since -the-great-depression/

Guiso, L., Sapienza, P., \& Zingales, L. (2018). Time Varying Risk Aversion. Journal of Financial Economics, 128, 403-421. https://doi.org/10.1016/j.jfineco.2018.02.007

Härle, P. et al. (2007). The Future of Bank Risk Management. https://www.mckinsey.com/ /media/mckinsey/dotcom/client service/risk/pdfs/the fu ture of bank risk management.ashx

Harris, P. R., Griffin, D. W., \& Murray, S. (2008). Testing the Limits of Optimistic Bias: Event and Person Moderators in a Multilevel Framework. Journal of Personality and Social Psychology, 95, 1225-1237. https://doi.org/10.1037/a0013315

Helms, K. (2020). Largest US Banks Expect Billions in Loan Losses, Profits Plunge. https://news.bitcoin.com/us-banks-billions-loan-losses/

Herschberg, M. (2012). Limits to Arbitrage: An Introduction to Behavioral Finance and a Literature Review. Palermo Business Review, No. 7, 7-23.

Ho, P. H., Huang, C. W., \& Yen, J. F. (2016). CEO Overconfidence and Financial Crisis: Evidence from Bank Lending and Leverage. Journal of Financial Economics, 120, 194-209. https://doi.org/10.1016/j.jfineco.2015.04.007

JPMorgan (2020). First Quarter Reveals Reality of COVID-19's Ongoing Impact. https://www.jpmorgan.com/solutions/cib/investment-banking/coronavirus-ongoing-i $\underline{\text { mpact }}$

Kasus COVID-19 (2020). Confirmed Cases in Indonesia. https://experience.arcgis.com/experience/bf4eb5d76e98423c865678e32c8937d4

King, F. J., Goodson, L. \& Rohani, F. (2018). Higher Order Thinking Skills: Definition, Teaching Strategies, \& Assessment. Florida: A Publication of the Educational Services Program, Now Known as the Center for Advancement of Learning and Assessment, Florida.

Langer, E. J. (1975). The Illusion of Control. Journal of Personality and Social Psychology, 32, 311-328. https://doi.org/10.1037/0022-3514.32.2.311

Lichtenstein, S., Fischhoff, B., \& Phillips, L. D. (1977). Calibration of Probabilities: The States of The Art. In H. Jungermann, \& G. De Zeeuw (Eds.), Decision Making and Change in Human Affairs (pp. 275-324). Dordrecht: Springer.

https://doi.org/10.1007/978-94-010-1276-8 19

Liu, Q., \& Zhang, L. (2014). Information Cascades in Online Reading: An Empirical Investigation of Panel Data. Emerald Insight, 32, 687-705.

https://doi.org/10.1108/LHT-06-2014-0052 
Manis, M., Shedler, J., Jonides, J., \& Nelson, T. E. (1993). Availability Heuristic in Judgments of Set Size and Frequency of Occurrence. Journal of Personality and Social Psychology, 65, 448-457. https://doi.org/10.1037/0022-3514.65.3.448

McCaffrey, P. M. (2020). Meir Statman on Coronavirus, Behavioral Finance: The Second Generation, and More.

https://blogs.cfainstitute.org/investor/2020/04/08/meir-statman-on-coronavirus-behavi oral-finance-the-second-generation-and-more/

Montesano, A. (1990). On the Definition of Risk Aversion. Theory and Decision, 29, 53-68. https://doi.org/10.1007/BF00134104

Moore, S. (2020). Researchers Examined the 2020 Market Crash. Here's What They Found.

https://www.forbes.com/sites/simonmoore/2020/09/08/researchers-examined-the-2020 -market-crash-heres-what-they-found/\#24c3963a6f18

O'Creevy, M., Nicholson, N., Soane, E., \& Willman, P. (2003). Trading on Illusions: Unrealistic Perceptions of Control and Trading Performance. Journal of Occupational and Organizational Psychology, 76, 53-68. https://doi.org/10.1348/096317903321208880

Olsen, R. A. (1998). Behavioral Finance and Its Implications for Stock-Price Volatility. Financial Analysts Journal, 54, 10-18. https://doi.org/10.2469/faj.v54.n2.2161

Ozili, P. K., \& Arun, T. (2020). Spillover of COVID-19: Impact on the Global Economy. SSRN. https://doi.org/10.2139/ssrn.3562570

Sedikides, C., \& Gregg, A. (2003). Portraits of the Self. In M. A. Hogg, \& J. Cooper (Eds.), Sage Handbook of Social Psychology (pp. 110-138). London: Sage.

Senarathne, C. W., \& Wei, J. (2020). Herd Behaviour in The Cryptocurrency Market: Fundamental vs Spurious Herding. The European Journal of Applied Economics, 17, 20-36. https://doi.org/10.5937/EJAE17-22053

Shiller, R. J. (2003). From Efficient Markets Theory to Behavioral Finance. Journal of Economic Perspectives, 17, 83-104. https://doi.org/10.1257/089533003321164967

Sironi, A., \& Suntheim, F. (2012). CEO Overconfidence in Banking. Milan: Bocconi University.

Skala, D. (2008). Overconfidence in Psychology and Finance-An Interdisciplinary Literature Review. Bank i Kredyt,4, 33-50.

Su, E. (2020). Capital Markets Volatility and COVID-19: Background and Policy Responses. https://crsreports.congress.gov/product/pdf/R/R46424

Taylor, S. E., \& Brown, J. (1994). Positive Illusion and Well-Being Revisited: Separating Fact from Fiction. Psychological Bulletin, 116, 21-27. https://doi.org/10.1037/0033-2909.116.1.21

Taylor, S. E., \& Brown, J. D. (1988). Illusion and Well-Being: A Social Psychological Perspective on Mental Health. Psychological Bulletin, 103, 193-210. https://doi.org/10.1037/0033-2909.103.2.193

Thakor, A. (2015). Lending Booms, Smart Bankers, and Financial Crises. American Economic Review, 105, 305-309. https://doi.org/10.1257/aer.p20151090

Trading Economics (2020). Indonesia Inflation Rate 2021-2022 Forecast. https://tradingeconomics.com/indonesia/inflation-cpi

Uslaner, E. M. (2010). Trust and the Economic Crisis of 2008. Corporate Reputation Review, 13, 110-123. https://doi.org/10.1057/crr.2010.8

Viswanathan, M. et al. (2017). Assessing the Risk of Bias in Systematic Reviews of Health Care Interventions. In Methods Guide for Effectiveness and Comparative Effectiveness 
Reviews. https://doi.org/10.23970/AHRQEPCMETHGUIDE2

Wälti, S. (2012). Trust No More? The Impact of the Crisis on Citizens Trust in Central Banks. Journal of International Money and Finance, 31, 593-605. https://doi.org/10.1016/j.jimonfin.2011.11.012

Wang, V. X., \& Xing, B. B. (2020). Battling Uncertainty: Corporate Disclosures of COVID-19 in Earnings Conference Calls and Annual Reports. SSRN. https://doi.org/10.2139/ssrn.3586085

Westbrook, T. (2020). FOREX-Dollar Slips as Optimism Holds Ahead of Fed. https://www.reuters.com/article/global-forex/forex-dollar-slips-as-optimism-holds-ahe ad-of-fed-idUSL3N2CH089

Yarovaya, L., Matkovskyy, R., \& Jalan, A. (2020). The Effects of a "Black Swan" Event (COVID-19) on Herding Behavior in Cryptocurrency Markets: Evidence from Cryptocurrency USD, EUR, JPY and KRW Markets. Journal of International Financial Markets, 1-57. https://doi.org/10.2139/ssrn.3586511

YCharts (2020). YCharts. https://ycharts.com/indicators/gold price in us dollar

Zhang, C. (2008). An Important Factor on Bearish Expectations of Investors: Application of Cognitive Biases in Market Forecasts. China Business Research of Economic Theory, 7, 73-74.

Zhang, D., Hu, M., \& Ji, Q. (2020). Financial Markets under the Global Pandemic of COVID-19. Finance Research Letters, 36, Article ID: 101528.

https://doi.org/10.1016/j.frl.2020.101528

Zhao, D., \& Fang, Y. (2014). Representation Bias, Return Forecast, and Portfolio Selection in the Stock Market of China. Mathematical Problems in Engineering, 2014, Article ID: 686201. https://doi.org/10.1155/2014/686201

Zíka, V., \& Koblovský, P. (2016). Optimism Bias and Overconfidence Effects in Managerial Decision Making. Prague Conference on Behavioral Sciences 2017: Modern Policy Making, Prague, November 2016, 1-11. 